\title{
For a new cultural economics
}

\author{
Federico Etro ${ }^{1} \cdot$ Douglas Noonan ${ }^{2}$
}

Published online: 8 February 2022

(c) The Author(s), under exclusive licence to Springer Science+Business Media, LLC, part of Springer Nature 2022

The Journal of Cultural Economics is getting close to half a century of life. It was founded in the 1970s, as were other top field journals in economics, and has contributed to shape theoretical and empirical research in cultural economics thanks to the precious contributions of an outstanding group of Associate Editors over many years. It is now time to renew the Editorial Board to face future challenges and developments in the field.

We want first of all to thank Associate Editors who have served the journal over the last years with dedication and unique competence, such as Darlene C. Chisholm (Suffolk University, USA), Alan Collins (University of Portsmouth, UK), Gillian Doyle (University of Glasgow, UK), Bruno Heyndels (Vrije Universiteit Brussel, Belgium), Jordi McKenzie (Macquarie University, Australia), Michael J. Rushton (Indiana University, USA), Bruce Seaman (Georgia State University, USA), Jen Snowball (Rhodes University, South Africa), Ruth Towse (Bournemouth University, UK), Patrick Waelbroeck (Ecole Nationale Supérieure des Telecommunications, France) and David Walls (University of Calgary, Canada). This year Victor Fernandez-Blanco (University of Oviedo, Spain) passed away, and we want to express our gratitude for his dedication to the journal.

The new Editorial Board will be composed of two groups of members: the Associate Editors will help the Co-editors in the ordinary editorial activity, serving for at least three years, while Honorary Members will have a permanent role. We are proud to announce here an outstanding team, whose components cover all the main areas of cultural economics and various geographical areas where our community is active. The team includes leading theoretical and empirical economists and in particular experts of cultural production and consumption, art creation and pricing, performing arts, music, movie theater industry and cinema, cultural urban economics, artistic labor markets, art investment, innovations and copyrights, economics of art history and collecting, heritage and cultural policy, digital markets, cultural trade and more. Jointly with the members of the Executive Board of the Association for

\footnotetext{
Federico Etro

federico.etro@unifi.it

1 University of Florence, Florence, Italy

2 Indiana University, Bloomington, USA
} 
Cultural Economics International, all the continents and the main local communities of scholars are represented.

Our new Associate Editors will be Simon Anderson (University of Virginia, USA), Victoria Ateca-Amestoy (University of the Basque Country, Spain), Karol Borowiecki (University of Odense, Denmark), Sam Cameron (Past Editor, UK), Pascal Courty (University of Victoria, Canada), Robert Ekelund (Auburn University, USA), Ricard Gil (Queen's University, Canada), William Goetzmann (Yale University, USA), Kazuko Goto (Setsunan University, Japan), Christian Handke (Erasmus University Rotterdam, Netherlands), Ana Flávia Machado (Federal University of Minas Gerais, Brazil), Silvia Marchesi (University of Milan Bicocca, Italy), Kim Oosterlinck (Université Libre of Bruxelles, Belgium), Abraham Ravid (Yeshiva University, USA), Ilde Rizzo (University of Catania, Italy), Christophe Spaenjers (HEC Paris, France) and Joel Waldfogel (University of Minnesota, USA). We are grateful to all of them for accepting to contribute to the editorial activity.

The Journal will also benefit from a new group of Honorary Members of the Editorial Board, including outstanding senior scholars in cultural economics. This group will start by including Orley Ashenfelter (Princeton University, USA), Bruno Frey (University of Zurich, Switzerland), David Galenson (University of Chicago, USA), Victor Ginsburgh (Université Libre de Bruxelles, Belgium), Kathryn Graddy (Brandeis University, USA) and David Throsby (Macquarie University, Australia). Their experience will be valuable for the strategic decisions of the journal.

Cultural economics is an expanding field that can still benefit from building more solid theoretical foundations and wider empirical investigations on artistic production and innovation, on the value of cultural resources - tangible and intangible - in society, on the structure of markets for the provision of cultural goods, on the evolution of cultural institutions, on the political economy of cultural policy, and more. Not just more 'big data' analysis, the future of cultural economics will be written by novel theoretical insights and empirical tests for research questions that can shape our understanding of cultural markets and policy issues. This is the legacy that great scholars like Ashenfelter, Frey, Galenson, Ginsburgh, Graddy, and Throsby have crafted for us. We also envision further progress in interdisciplinary areas that deserve further work, including the economics of art history, theories of artistic creation and trade, behavioral cultural economics, discrimination and structural inequities in art markets and the cultural sector, cultural urban economics, and emerging market and non-market environments where an economic approach yields important insights. We look forward to contributions in these and more traditional areas of our field.

In conclusion, we take this opportunity to publicize a new Call for Papers for a Special Issue on "The Economics of Art History". The Guest Co-Editor of this issue will be David Galenson of the Department of Economics of the University of Chicago and a new member of our Board. We solicit empirical and theoretical submissions about economic and quantitative aspects of art history to potentially be included in this special issue. Further details can be found in the journal website.

Publisher's Note Springer Nature remains neutral with regard to jurisdictional claims in published maps and institutional affiliations. 